\title{
Pengaruh Penggunaan Video Pembelajaran IPA Terhadap Minat Belajar Siswa Kelas III SD Inpres Lanraki 2 Kecamatan Tamalanrea Kota Makassar
}

\author{
Hamzah Pagarra ${ }^{1}$, Nur Abidah Idrus ${ }^{2}$ \\ ${ }^{1,2}$ Program Studi PGSD, Fakultas Ilmu Pendidikan, Universtas Negeri Makassar \\ 1hamzah.pagarra@gmail.com \\ nur_abidah@yahoo.com
}

\begin{abstract}
ABSTRAK
Tujuan penelitian ini adalah 1) Untuk mengetahui gambaran penggunaan media video pembelajaran IPA kelas III SD Inpres Lanraki 2 Kecamatan Tamalanrea Kota Makassar, 2) Untuk mengetahui gambaran minat belajar siswa kelas III SD Inpres Lanraki 2 Kecamatan Tamalanrea Kota Makassar, 3) Untuk mengetahui pengaruh penggunaan video pembelajaran IPA terhadap minat belajar siswa kelas III SD Inpres Lanraki 2 Kecamatan Tamalanrea Kota Makassar. Penelitian ini menggunakan pendekatan kuantitatif. Pada pendekatan ini data akan dianalisis secara kuantitatif dengan menggunakan statistik untuk menguji hipotesis yang telah disiapkan.Jenis penelitian yang digunakan dalam peneilitian ini adalah Pre-Eksperimental dengan desain penelitian One Group Pretest-Posttest design. Populasi dan sampel penelitian ini adalah siswa kelas III SD Inpres Lanraki 2 Tahun ajaran 2016/2017. Teknik pengumpulan data dalam penelitian ini yaitu: angket, lembar observasi, dan dokumentasi. Adapun teknik analisis data yang digunakan dalam penelitian ini adalah analisis statistik deskriptif dan analisis statistik inferensial. Untuk melihat perbedaan tersebut maka data dianalisis dengan menggunakan uji Paired Sample t-Test. Berdasarkan hasil uji hipotesis dengan statistik inferensial menunjukkan ada pengaruh yang signifikan penggunaan media video pembelajaran terhadap minat belajar Ilmu Pengetahuan Alam.
\end{abstract}

Kata kunci: media video, minat belajar, video pembelajaran

\section{PENDAHULUAN}

Pendidikan sebagai usaha manusia untuk menumbuh kembangkan potensi-potensi bawaan baik jasmani ataupun rohani untuk memperoleh hasil dan prestasi, sehingga ia mencapai kedewasaan dan menjadi manusia yang utuh.

Pendidikan merupakan suatu upaya untuk mewujudkan sumber daya manusia yang berkualitas. Untuk mencapai hal ini, diperlukan suatu pendukung yaitu kiat dalam meningkatkan mutu pendidikan. Pendidikan juga dikatakan sebagai proses pembentukan pribadi.(pagarra, 2016)

Menurut undang-undang Nomor 20 tahun 2003 tentang sistem pendidikan nasional: Pendidikan adalah usaha sadar terencana untuk mewujudkan suasana belajar dan proses pembelajaran agar peserta didik secara aktif mengembangkan potensi dirinya untuk memiliki kekuatan spiritual keagamaan, pengendalian diri, kepribadian, kecerdasan, akhlak mulia, serta keterampilan yang diperlukan darinya, masyarakat, bangsa dan negara.
Dalam undang-undang tersebut memberikan konsep bahwa pendidikan merupakan suatu proses pembentukan pribadi yang diartikan sebagai suatu kegiatan yang sistematis dan terarah kepada terbentuknya kepribadian peserta didik. Oleh karena itu harus dipahami dan didasari oleh seluruh segmentasi pendidikan agar pendidikan terarah pada tujuan dan aktivitas pendidikan khususnya pada pendidikan sekolah dasar. Pendidikan dasar merupakan pembentukan awal atau tahap dasar dalam upaya meningkatkan mutu sumber daya manusia (SDM) sebagai generasi penerus bangsa.

Mata Pelajaran Ilmu Pengetahuan Alam (IPA) adalah salah satu mata pelajaran yang memiliki peranan penting dalam membelajarkan siswa tentang alam semesta. Undang-Undang Nomor 20 Tahun 2003 pasal 37 ayat 1 dijelaskan bahwa, "Ilmu Pengetahuan Alam merupakan salah satu mata pelajaran yang wajib ada pada pendidikan dasar dan menengah".

Berdasarkan penjelasan tersebut maka mata pelajaran IPA merupakan bekal siswa untuk dapat memiliki pengetahuan dan 
wawasan tentang konsep dasar peristiwaperistiwa alam di sekitarnya, sehingga siswa dapat memahami bahwa setiap kejadian yang berhubungan dengan alam yang ada di lingkungan mereka tidaklah terjadi begitu saja, namun ada proses-proses yang terlebih dahulu terjadi. Dalam mata pelajaran IPA siswa tidak semata-mata diajarkan untuk mengerti bahkan memahami konsep IPA itu sendiri akan tetapi dalam pembelajaran siswa diharapkan untuk menumbuhkan sikap ilmiah. Selain itu, siswa diharapkan dapat berperan aktif dalam memelihara lingkungan alam sekitar mereka. Akan tetapi, tujuan tersebut tidak akan tercapai oleh siswa ketika guru kurang mampu menyampaikan materi ajar dengan baik. Hal ini berarti bahwa guru mempunyai peranan yang sangat penting terhadap tercapai atau tidaknya tujuan pembelajaran yang telah ditetapkan.

Pada proses belajar mengajar peranan guru sangat penting. Menurut UU RI No. 14 tahun 2005 tentang Guru dan Dosen, "Guru adalah pendidik profesional dengan tugas utama mendidik, mengajar, membimbing, melatih dan mengevaluasi siswa pada pendidikan anak usia dini jalur pendidikan formal, pendidikan dasar, dan pendidikan menengah". Berdasarkan rumusan Undangundang tersebut, dapat dilihat bahwa guru memilki peran yang sangat penting untuk mendidik ataupun membimbing siswa untuk memahami materi pembelajaran.

Guru dalam melaksanakan proses pembelajaran sebaiknya menciptakan kondisi atau situasi yang menyenangkan sehingga membuat siswa dapat bersemangat menerima pelajaran dan memudahkan penyampaian materi pelajaran. Menurut Sutanto (2013) bahwa, permasalahan yang dihadapi oleh guru dalam pembelajaran IPA adalah motivasi dan minat siswa terhadap materi pelajaran yang rendah, sehingga membuat siswa tidak aktif dalam pembelajaran, yang pada akhirnya menyebabkan hasil belajarnya tidak tercapai secara maksimal. Untuk itu, dalam proses pembelajaran perlu sebuah penanganan oleh guru. Salah satu usaha guru dalam menciptakan kondisi pembelajaran yang menyenangkan adalah penggunaan media pembelajaran secara optimal.

Media pembelajaran memiliki peranan penting dalam proses pembelajaran. Hal ini sesuai dengan pendapat Hamalik (Arsyad, 2016 : 19) mengemukakan bahwa, "pemakaian media pembelajaran dalam proses belajar mengajar dapat membangkitkan keinginan dan minat yang baru, membangkitkan motivasi dan rangsangan kegiatan belajar, dan bahkan membawa pengaruh - pengaruh psikologi terhadap siswa". Oleh sebab itu, guru harus lebih memperhatikan media apa yang akan digunakannya dalam pembelajaran dengan mengkombinasikan berbagai jenis media dalam satu pembelajaran seperti menggabungkan media berbasis audio dan visual untuk menyampaikan materi pembelajaran agar pesan bisa diserap dengan baik oleh semua peserta didik.

Peneliti melakukan wawancara untuk mengetahui bagaimana gambaran proses pembelajaran siswa dalam mengikuti mata pelajaran IPA. Wawancara dilakukan dengan wali kelas III yaitu Ibu Nursyafitriah,S.Pd pada tanggal 17 Januari 2017. Dalam proses pembelajaran guru mengalami kendala dalam penggunaan media pembelajaran dikarenakan sarana dan prasarana yang kurang memadai dan kondisi siswa yang terlihat bosan pada saat guru menyampaikan materi.

Peneliti juga melakukan pengamatan pada saat proses pembelajaran IPA di kelas III SD Inpres Lanraki 2 Kecamatan Tamalanrea Kota Makassar pada bulan Januari - Februari 2017, beberapa permasalahan dalam proses pembelajaran: (1) dalam proses pembelajaran IPA media video pembelajaran yang kurang optimal dikarenakan sarana dan prasarana yang kurang memadai, (2) peserta didik kurang memahami materi yang sedang dipelajari sehingga membuat kegiatan sendiri ditempat duduknya, (3) dari 30 orang siswa dikelas III A hanya 9 orang siswa yang berperan aktif dalam pembelajaran.

Berdasarkan permasalahan yang ada perlu dilakukan suatu perubahan yang dirancang sedemikian rupa sehingga dapat mengatasi masalah tersebut. Adapun solusi yang dibutuhkan ialah pemanfaatan media pembelajaran yang mampu meningkatkan minat siswa. Pada era perkembangan teknologi yang begitu pesat seperti sekarang ini, ada berbagai alat maupun aplikasi yang dapat digunakan guru untuk media pembelajaran yang menarik dan variatif serta dapat mengakomodir tipe-tipe belajar siswa, khususnya dalam pembelajaran IPA guru dapat melakukan rekayasa terhadap peristiwaperistiwa alam dengan menggunakan aplikasi yang telah ada.

Video pembelajaran sebagai salah satu alternatif solusi bagi guru dalam menyediakan media pembelajaran untuk membantu guru menyampaikan materi pembelajaran agar lebih 
menarik bagi peserta didik. Pembelajaran yang menggunakan video dapat digunakan untuk menunjukkan bukti-bukti tentang kejadian alam yang telah dibuat sedemikian rupa. Penggunaan Video memiliki beberapa keunggulan yaitu dapat dilihat dan didengar secara berulang, dan dapat memberi stimulus secara stimultan terhadap berbagai indera, serta membantu kejelasan informasi dan memori. Visualisasi fenomena alam dapat memperjelas hasil pengamatan dan dapat memberikan kontribusi dalam peningkatan pemahaman siswa. Video itu sendiri menurut Cecep Sutandi (Thomas, 2015) adalah alat yang dapat menyajikan informasi, memaparkan proses, menjelaskan konsepkonsep yang rumit, mengajarkan keterampilan, menyingkat atau memperlambat waktu dan mempengaruhi sikap.

Penggunaan media video dalam pembelajaran diyakini mampu membantu peningkatan minat belajar siswa. Minat belajar siswa sangat bergantung kepada proses guru dalam menyampaikan pembelajaran dan dengan minat pula siswa mampu mencapai hasil belajar yang memuaskan. Adanya minat dapat membuat siswa menjadi tertarik dan perhatian terhadap pembelajaran sehingga dari minat tersebut, siswa ingin untuk mempelajari lebih dalam tentang materi mata pelajaran yang diajarkan. Oleh karena itu, minat dikatakan sebagai satu hal yang penting dalam membantu siswa untuk meningkatkan hasil belajarnya. Selain itu terdapat beberapa penelitian yang relevan tentang Penerapan Media Video Pembelajaran dan salah satunya penelitian yang dilakukan oleh Adriani yang membuktikan dengan penerapan video pembelajaran maka dapat meningkatkan minat siswa dalam belajar IPA (Adriani,2016).

Berkaitan dengan hal itu, maka upaya mengatasi permasalahan tersebut penulis mengkajinya melalui penelitian eksperimen dengan judul "Pengaruh Penggunaan Media Video Pembelajaran IPA Terhadap Minat Belajar Siswa Kelas III SD Inpres Lanraki 2 Kecamatan Tamalanrea Kota Makassar”.

\section{METODE PENELITIAN}

Penelitian ini menggunakan pendekatan kuantitatif. Pada pendekatan ini data akan dianalisis secara kuantitatif dengan menggunakan statistik untuk menguji hipotesis yang telah disiapkan. Jenis penelitian yang digunakan dalam peneilitian ini adalah PreEksperimental dengan desain penelitian One Group Pretest-Posttest design. Peneliti menggunakan desain ini untuk mengetahui pengaruh penggunaan media video pembelajaran IPA terhadap minat belajar siswa kelas III SD Inpres Lanraki II Kota Makassar. Populasi dari penelitian ini adalah seluruh siswa kelas III SD Inpres Lanraki 2 Tahun ajaran 2016 /2017 yang berjumlah 2 kelas dengan jumlah populasi adalah sebanyak 60 siswa. Teknik penarikan sampel yang digunakan dalam penelitian ini dilakukan dengan teknik purposive sampling. Adapun sampel dalam penelitian ini adalah kelas III A yang terdiri dari 30 orang siswa.

Teknik pengumpulan data utama dalam penelitian ini adalah angket, observasi dan Dokumentasi. Adapun teknik analisis data yang digunakan dalam penelitian ini adalah Analisis Statistik Deskriptif dan Analisis Statistik Inferensial. Analisis statistik inferensial dimaksudkan untuk menguji hipotesis penelitian, sebelum pengujian hipotesis terlebih dahulu dilaksanakan uji prasyarat data berupa uji normalitas. Uji hipotesis dilakukan untuk mengetahui ada tidaknya perbedaan minat belajar IPA sebelum dan setelah dibelajarkan dengan menggunakan media video pembelajaran. Untuk melihat perbedaan tersebut maka data dianalisis dengan menggunakan uji Paired Sample t-Test. Pengujian ini dilakukan dengan bantuan sistem Statistical Pachage for Social Science (SPSS).

\section{HASIL \& PEMBAHASAN}

Penelitian ini dilaksanakan dengan terlebih dahulu meminta persetujuan Kepala Sekolah SD Inpres Lanraki II Kecamatan Tamalanrea Kota Makassar mengenai penelitian yang akan dilaksanakan. Setelah itu peneliti melakukan observasi ke kelas yang akan diteliti dan menyepakati jadwal penelitian yang akan dilakukan. Penelitian pertama kali dilakukan pada tanggal 10 April 2017 untuk pemberian tes awal (pretest) pada kelas III A. Sebelum peneliti melakukan tes awal (pretest), peneliti terlebih dahulu melakukan uji validitas instrumen angket minat belajar. Uji validitas yang dilakukan adalah uji validitas ahli. Peneliti tidak menggunakan validitas konstruk karena menggunakan 2 validator ahli. Uji ahli yaitu menguji item pernyataan angket minat belajar kepada ahli yang berhubungan dengan keilmuan validator mengenai minat belajar. Adapun validator pertama instrumen dalam penelitian ini menjelaskan bahwa berdasarkan 36 item pernyataan dari 4 aspek yang dinilai, didapatkan hasil bahwa 8 item dinyatakan perlu diganti. Kemudian validator kedua 
menjelaskan bahwa dari 36 item pernyataan dari 4 aspek yang dinilai, didapatkan hasil 4 item dinyatakan perlu diganti. Item yang dinyatakan diganti telah diperbaiki oleh kedua validator sehingga seluruh item angket minat belajar dapat digunakan untuk penelitian minat belajar siswa. Karena jumlah item terlalu banyak untuk diberikan kepada anak kelas 3, maka peneliti mengurangi 6 item pernyataan.

Adapun hasil yang diperoleh dalam penelitian ini dianalisis dengan menggunakan statistik deskriptif untuk menyatakan distribusi frekuensi skor siswa dan pengolahan statistik inferensial sebagai pengujian hipotesis. Analisis statistik deskriptif dilakukan dengan cara sebagai berikut:

\section{Analisis Statistik Deskriptif}

Analisis statistik deskriptif memberikan informasi penting mengenai gambaran data yang diperoleh di lapangan untuk kemudian disajikan dalam bentuk yang lebih ringkas dan sederhana yang pada akhirnya mengarah pada keperluan adanya penjelasan dan penafsiran. Untuk melihat gambaran penggunaan media video pembelajaran, maka peneliti menggunakan lembar observasi guru untuk melihat keadaan tersebut.

Perlakuan yang diberikan dalam penelitian ini berupa penggunaan media video pembelajaran IPA di kelas III SD Inpres Lanraki II Kecamatan Tamalanrea Kota Makassar.

Pengguanaan media video pada mata pelajaran IPA di kelas III SD Inpres Lanraki II memberikan pengaruh positif terhadap peningkatan minat belajar siswa. Ini dibuktikan dengan hasil pengamatan yang telah dilakukan baik itu kepada siswa maupun kepada guru. Berdasarkan hasil pengamatan yang telah dilakukan dalam proses pembelajaran IPA dengan menggunakan video pembelajaran, hasil pelaksanaan tersebut dapat dilihat pada tabel berikut:

Tabel 1. Gambaran Penggunaan Media Video Pembelajaran IPA Kelas III SD Inpres Lanraki II Kecamatan Tamalanrea Kota Makassar

\begin{tabular}{clccc}
\hline \multirow{2}{*}{ No } & \multicolumn{1}{c}{$\begin{array}{c}\text { Kegiatan yang } \\
\text { Diamati }\end{array}$} & Pertemuan 1 & Pertemuan 2 & Pertemuan 3 \\
\hline 1. & Pembuka & 2 & 3 & 3 \\
\hline 2. & $\begin{array}{l}\text { Penyampaian } \\
\text { Materi Menggunakan video }\end{array}$ & 2 & 3 & 3 \\
\hline 3. & $\begin{array}{l}\text { Menjelaskan } \\
\text { Ulang Materi Pembelajaran }\end{array}$ & 3 & 3 & 3 \\
\hline 4. & $\begin{array}{l}\text { Pemberian Penguatan } \\
\text { (reinforcement) }\end{array}$ & 1 & 2 & 2 \\
\hline 5. & $\begin{array}{l}\text { Penutup } \\
\quad\end{array}$ & 2 & 2 & 2 \\
\hline & Total & $\mathbf{1 0}$ & $\mathbf{1 3}$ & $\mathbf{1 3}$ \\
\hline
\end{tabular}

Berdasarkan tabel tersebut ada 5 aspek yang diamati selama proses pembelajaran terdiri dari kegiatan pembuka, menyampaikan materi menggunakan video pembelajaran, menjelaskan ulang materi pembelajaran, pemberian penguatan dan penutup. Masingmasing aspek tersebut diamati dan diukur berdasarkan 3 indikator pencapaian yang telah disusun setiap aspeknya. Aspek pertama pada kegiatan pembuka, indikatornya guru menyapa dan menanyakan kabar siswa, apersepsi, menyampaikan tujuan pembelajaran. Aspek kedua yaitu penyampaian materi menggunakan video pembelajaran, indikatornya menjelaskan secara global mengenai isi dalam video yang akan ditampilkan, memusatkan perhatian siswa pada video pembelajaran akan ditampilkan, menampilkan video pembelajaran yang berkaitan dengan materi. Aspek ketiga yaitu menjelaskan ulang materi pembelajaran, indikatornya menjelaskan kembali materi yang telah ditampilkan pada video pembelajaran, guru menggunakan bahasa yang mudah dipahami siswa, memberikan kesempatan kepada siswa untuk mengungkapkan pendapat atau bertanya. Aspek keempat yaitu pemberian penguatan, indikatornya menyebutkan kata bagus, pintar dan kata pujian lainnya, 
memberikan pujian nonverbal seperti memberikan tepuk tangan dan jempol pada siswa. Aspek kelima yaitu penutup, indikatornya menyimpulkan materi pembelajaran, mengingatkan siswa tentang pentingnya materi yang telah dipelajari dan memotivasi siswa untuk mengulangi pelajaran di rumah. Langkah-langkah tersebut telah dilaksanakan dengan baik oleh guru dari pertemuan I sampai III dengan persentase pelaksanaannya pada pertemuan pertama $71,42 \%$, pertemuan kedua $92,85 \%$ dan pertemuan ketiga $92,85 \%$. Persentase pencapaian tersebut diperoleh dengan membagi skor indikator yang dicapai dengan skor maksimal dikali $100 \%$.

Pelaksanaan pembelajaran yang dilakukan oleh guru dengan menggunakan media video pembelajaran memberikan stimulus kepada siswa sehingga siswa merespon pembelajaran. Hasil observasi aktivitas siswa dengan jumlah siswa pada kelompok eksperimen sebanyak 30 siswa dan masing-masing siswa mencapai indikator yang berbeda-beda.

Adapun gambaran aktivitas siswa dapat dilihat berdasarkan tabel berikut ini:

Tabel 2. Hasil Observasi Aktivitas Siswa

\begin{tabular}{ccccc}
\hline \multirow{2}{*}{ No } & Aspek & \multicolumn{3}{c}{ Persentase (\%) } \\
\cline { 3 - 5 } & Pertemuan 1 & Pertemuan 2 & Pertemuan 3 \\
\hline 1. & Perasaan suka & $75,56 \%$ & $93,33 \%$ & $97,78 \%$ \\
\hline 2. & $\begin{array}{l}\text { Perhatian siswa } \\
\text { terhadap mata } \\
\text { pelajara IPA }\end{array}$ & $73,33 \%$ & $86,67 \%$ & $87,78 \%$ \\
\hline 3. & $\begin{array}{l}\text { Ketertarikan siswa } \\
\text { terhadap mata } \\
\text { pelajara IPA }\end{array}$ & $67,78 \%$ & $76,67 \%$ & $83,33 \%$ \\
\hline
\end{tabular}

Berdasarkan tabel tersebut, ada 3 aspek yang diamati yaitu perasaan suka, perhatian siswa terhadap mata pelajaran IPA, dan ketertarikan siswa terhadap mata pelajaran. Masing-masing aspek tersebut diamati dan diukur berdasarkan 3 indikator pencapaian yang telah disusun setiap aspeknya. Aspek pertama yaitu perasaan suka, indikatornya mengikuti arahan dan intruksi dari guru, tidak mengganggu temannya ketika guru menjelaskan, siswa antusias menjawab ketika guru memberikan pertanyaan tentang media yang telah ditayangkan. Aspek kedua yaitu perhatian siswa terhadap mata pelajaran, indikatornya siswa tidak menunjukkan sikap acuh terhadap pembelajaran, siswa mendengarkan dan memperhatikan video yang ditayangkan, memberi tanggapan dari pendapat guru maupun sesama teman. Aspek ketiga yaitu ketertarikan siswa terhadap mata pelajaran, indikatornya siswa tidak merasa tegang saat mengikuti pembelajaran, menunjukkan sikap tenang ketika guru menjelaskan, aktif berpartisipasi dalam kegiatan pembelajaran.
Berdasarkan hasil observasi tersebut, diperoleh bahwa respon siswa pada pembelajaran IPA dengan menggunakan media video pembelajaran membuat siswa lebih senang dan tertarik dalam mengikuti pembelajaran IPA.

Adapun cara untuk melihat gambaran minat belajar siswa, maka peneliti menggunakan pretest untuk melihat keadaan tersebut. Angket yang telah di uji ahli kemudian diberikan kepada siswa. Dalam angket tersebut terdapat pernyataan positif sebanyak 15 nomor dan pernyataan negatif sebanyak 15 nomor dengan pilihan jawaban (a) sangat sesuai; (b) Sesuai; (c) tidak sesuai; (d) sangat tidak sesuai. Hasil yang didapatkan kemudian dimasukkan ke dalam tabel untuk digambarkan secara kuantitatif.

\section{a. Data Pretest siswa tentang minat belajar Ilmu Pengetahuan Alam}

Penentuan nilai kuantitatif pretest siswa adalah dengan menjumlahkan skor jawaban angket dari responden sesuai dengan frekuensi jawaban. 
Tabel 3 Tabel Distribusi Frekuensi Pretest Hasil Jawaban Siswa Kelas III SD Inpres Lanraki II Kecamatan Tamalanrea Kota Makassar

\begin{tabular}{lc}
\hline Statistik Deskriptif & Nilai \\
\cline { 2 - 2 } Jumlah Sampel & Pretest \\
\hline Nilai Terendah & 30 \\
\hline Nilai Tertinggi & 54,00 \\
\hline Rata-Rata (Mean) & 97,00 \\
\hline Rentang (Range) & 75,8667 \\
\hline Standar Deviasi & 43,00 \\
\hline Median & 10,93786 \\
\hline Modus & 74,00 \\
\hline
\end{tabular}

Berdasarkan hasil analisis tentang minat belajar IPA sebelum diberikan perlakuan, maka diperoleh skor sebagai berikut: jumlah sampel banyak 30 siswa, nilai maksimum adalah 97,00 dan nilai minimum adalah 54,00. Adapun rata-rata yang diperoleh sebesar 75.8667, median 74,00 dan modus sebesar 77,00 .

Berdasarkan tabel tersebut dapat diketahui bahwa dari jumlah sampel sebanyak 30 siswa diperoleh bahwa terdapat beberapa sampel yang memiliki nilai terendah yaitu 54,00 dan nilai tertinggi 97,00 dan dari jumlah keseluruhan data dengan dibagi banyaknya siswa dalam penelitian ini diperoleh bahwa rata-rata siswa memperoleh nilai 75,8667 . Sedangkan dalam peneltian ini nilai yang paling sering muncul atau nilai yang frekuensi terbesar yang diperoleh oleh sampel adalah nilai 77,00. Range (Rentang) menunjukan kualitas suatu data, rentang nilai yang diperoleh adalah hasil pemgurangan dari nilai maksimum dan nilai minimum semakin kecil rentang nilai suatu data maka semakin baik kualtiasnya, begitupun sebaliknya sehingga rentang data yang diperoleh dalam penelitian ini adalah 43,00. Standar deviasi yang diperoleh 10,93786 yang artinya data dalam kelompok bervariasi. Standar deviasi adalah salah satu teknik statistik yang digunakan untuk menjelaskan homogenitas kelompok. Standar deviasi merupakan sebaran data semakin kecil nilai sebarannya berarti variasi nilai data semakin sama.

Hasil analisis deskriptif untuk hasil jawaban pretest siswa berhubungan dengan variabel terikat yaitu minat belajar IPA yang disajikan sebagai berikut:

Tabel 4 Kualifikasi dan Interval Pretest Siswa

\begin{tabular}{cccccc}
\hline $\begin{array}{c}\text { Nilai } \\
\text { Interval }\end{array}$ & $\begin{array}{c}\text { Rata- } \\
\text { rata }\end{array}$ & Kualifikasi & Kategori & Frekuensi & $\begin{array}{c}\text { Persentase } \\
\text { Kumulatif }\end{array}$ \\
\hline $91-120$ & & Tinggi & & 4 & $13,33 \%$ \\
\hline $61-90$ & 75,8667 & Sedang & Sedang & 25 & $83,33 \%$ \\
\hline $30-60$ & & Rendah & & 1 & $3,33 \%$ \\
\hline
\end{tabular}

Data dalam tabel tersebut menunjukkan bahwa terdapat 1 siswa atau $3,33 \%$ siswa menyatakan bahwa minat belajar IPA berada pada kategori rendah dan 25 siswa atau $83,33 \%$ siswa pada taraf sedang 4 orang siswa atau $13,33 \%$ pada taraf tinggi.

Berdasarkan uraian tersebut ditemukan bahwa minat belajar IPA siswa sebelum diberikan perlakuan atau treatment dalam taraf sedang. Hal ini berdasarkan analisis jawaban angket pretest siswa bahwa pada angket indikator minat belajar terdapat indikator yang masih rendah. Dalam indikator minat belajar terdapat beberapa aspek yaitu: 1) Perasaan suka; 2) Keterlibatan siswa; 3) Perhatian siswa terhadap mata pelajaran; 4) Ketertarikan siswa 
terhadap mata pelajaran. Minat siswa yang berada dalam kategori sedang berdasarkan analisis angket terdapat aspek yang masih kurang yaitu masih kurangnya perasaan suka, keterlibatan siswa dalam pembelajaran,dan keteratarikan siswa terhadap mata pelajaran IPA.

\section{b. Data Posttest siswa tentang minat belajar Ilmu Pengetahuan Alam}

Penentuan nilai kuantitatif posttest siswa adalah dengan menjumlahkan skor jawaban angket dari responden sesuai dengan frekuensi jawaban.

\begin{tabular}{cc} 
Tabel 5 Tabel Distribusi Frekuensi Posttest & Hasil Jawaban Angket Siswa \\
Kelas III SD Inpres Lanraki II Kecamatan Tamalanrea Kota Makassar \\
\cline { 2 - 2 } Statistik Deskriptif & Nilai \\
\hline Jumlah Sampel & Posttest \\
\hline Nilai Terendah & 90 \\
\hline Nilai Tertinggi & 98,00 \\
\hline Rata-Rata (Mean) & 120,00 \\
\hline Rentang (Range) & 109,6667 \\
\hline Standar Deviasi & 22,00 \\
\hline Median & 5,70743 \\
\hline Modus & 109,00 \\
\hline
\end{tabular}

Berdasarkan hasil analisis tentang minat belajar IPA setelah diberikan perlakuan, maka diperoleh skor sebagai berikut: jumlah sampel sebanyak 30 siswa, nilai maksimum 120,00 dan nilai minimum adalah 98,00 . Adapun nilai mean yang diperoleh adalah sebesar 109,6667, median sebesar 109,00 dan modus sebesar 103,00 .

Berdasarkan tabel dapat diketahui bahwa dari jumlah sampel sebanyak 30 siswa diperoleh bahwa terdapat beberapa sampel yang memiliki nilai terendah yaitu 98,00 dan nilai tertinggi 120 dan dari jumlah keseluruhan data dengan dibagi banyaknya siswa dalam penelitian ini diperoleh bahwa rata-rata siswa memperoleh nilai 109,6667 Sedangkan dalam peneltian ini nilai yang paling sering muncul atau nilai yang frekuensi terbesar yang diperoleh oleh siswa adalah nilai 103. Range
(Rentang) menunjukan kualitas suatu data, rentang nilai yang diperoleh adalah hasil pemgurangan dari nilai maksimum dan nilai minimum semakin kecil rentang nilai suatu data maka semakin baik kualtiasnya, begitupun sebaliknya sehingga rentang data yang diperoleh dalam penelitian ini adalah 22,00. Standar deviasi yang diperoleh 5,70743 yang artinya data dalam kelompok sedikit bervariasi. Standar deviasi adalah salah satu teknik statistik yang digunakan untuk menjelaskan homogenitas kelompok. Standar deviasi merupakan sebaran data semakin kecil nilai sebarannya berarti variasi nilai data semakin sama.

Hasil analisis deskriptif untuk hasil jawaban postest siswa berhubungan dengan variabel terikat yaitu minat belajar IPA yang disajikan sebagai berikut:

Tabel 6 Kualifikasi dan Interval Posttest Siswa

\begin{tabular}{cccccc}
\hline $\begin{array}{c}\text { Nilai } \\
\text { Interval }\end{array}$ & Rata-rata & Kualifikasi & Kategori & Frekuensi & $\begin{array}{c}\text { Persentase } \\
\text { Kumulatif }\end{array}$ \\
\hline $\mathbf{9 1 - 1 2 0}$ & & Tinggi & & 30 & $100 \%$ \\
\hline $\mathbf{6 1 - 9 0}$ & 109,6667 & Sedang & Tinggi & 0 & 0 \\
\hline $\mathbf{3 0 - 6 0}$ & & Rendah & & 0 & 0 \\
\hline
\end{tabular}


Data dalam tabel tersebut menunjukkan bahwa terdapat seluruh siswa menyatakan bahwa minat dalam belajar IPA berada dalam kategori tinggi. Hal ini menujukkan bahwa setelah belajar IPA dengan menggunakan video pembelajaran maka minat belajar siswa yang sebelumnya sedang berada pada taraf tinggi.

\section{Analisis Statistik Inferensial}

Analisis statistik inferensial digunakan untuk menguji hipotesis penelitian, dalam penelitian ini data dianalisis dengan menggunakan bantuan Statistical Package for Social Science (SPSS). Sebelum melakukan pengujian hipotesis, terlebih dahulu dilakukan uji normalitas data untuk mengetahui data berdistribusi normal atau tidak, setelah itu baru dilakukan pengujian hipotesis. a. Uji Normalitas Data

Adapun kriteria pengujian normalitas data yaitu jika nilai sig. (2-tailed) yang diperoleh $>0,05$ maka dapat dikatakan bahwa data berdistribusi normal, sebaliknya jika sig. (2-tailed) yang diperoleh $<0,05$ maka dapat dikatakan bahwa data tidak berdistribusi normal.

Dari hasil analisis menggunakan SPSS diperoleh nilai sig. (2-tailed) pretest sebesar 0,436 dan nilai sig. (2-tailed) posttest sebesar 0,865 . Hal ini menunjukkan bahwa 0,436 dan $0,865>0,05$, maka dapat disimpulkan bahwa data berdistribusi normal, sehingga data dapat dilanjutkan ke tahap selanjutnya yaitu uji hipotesis.

Hasil uji normalitas data menggunkan SPSS dapat dilihat pada tabel berikut:

Tabel 7 Hasil Uji Normalitas data $\alpha(0,05)$

\begin{tabular}{cl}
\hline Pretest & Posttest \\
\hline$p$-value $>\alpha$ & $p$-value $>\alpha$ \\
$0,436>0,05$ & $0,865>0.05$ \\
\hline
\end{tabular}

\section{b. Uji hipotesis}

Setelah diketahui bahwa nilai hasil pretes dan posttest berdistribusi normal maka selanjutnya dilakukan uji hipotesis. Uji hipotesis ini dilakukan untuk mengetahui ada tidaknya pengaruh penggunaan media video pembelajaran IPA terhadap minat belajar siswa kelas III SD Inpres Lanraki II Kecamatan Tamalanrea Kota Makassar. Data dianalisis dengan menggunakan bantuan SPSS dengan kriteria pengujian sebagai berikut:

1) Jika sig. (2-tailed) $>0,05$ maka Ho diterima 2) Jika sig. (2-tailed $)<0,05$ maka Ha ditolak

Dari hasil analisis menggunakan bantuan SPSS diperoleh nilai sig. (2-tailed) sebesar 0,000. Hal ini menunjukkan bahwa nilai sig. (2-tailed) $0,000<0,05$ dapat disimpulkan bahwa Ha ditolak, yang berarti terdapat pengaruh penggunaan media video pembelajaran IPA terhadap minat belajar siswa kelas III SD Inpres Lanraki 2 Kecamatan Tamalanrea Kota Makassar. Hasil analisis SPSS dapat dilihat pada lampiran 21 halaman 112.

\section{Pembahasan}

Penelitian pre-eksperimental ini, peneliti melakukan penelitian pada kelas III A SD Inpres Lanraki II Kecamatan Tamalanrea Kota Makassar sebagai kelas eksperimen dengan jumlah siswa 30 orang yang terdiri dari 12 siswa perempuan dan 18 siswa laki-laki. Desain penelitian yang digunakan dalam penelitian ini adalah One Group PretestPosttest Design yang hanya melibatkan satu kelompok eksperimen dimana diberi tes awal berupa pretest dan pada akhir pembelajaran diberikan posttest.

Teknik pengumpulan data yang dilakukan yang pertama adalah angket minat belajar. Angket merupakan teknik yang berguna memperoleh data tentang penerapan video pembelajaran terhadap minat belajar Ilmu Pengetahuan Alam. Angket minat belajar yang disajikan bersifat tertutup, sehingga siswa hanya mengisi alternatif jawaban yang disediakan. Kedua, lembar observasi. Kegiatan observasi dilakukan terhadap guru dan siswa. Observasi yang dilakukan pada guru melihat pelaksanaan pembelajaran menggunakan media video pembelajaran, sedangkan pada siswa digunakan untuk melihat minat belajar siswa ketika menggunakan media video 
pembelajaran. Pada saat pembelajaran berlangsung, ada 3 aspek yang diperhatikan pada minat belajar siswa, yakni perasaan suka, perhatian siswa terhadap mata pelajaran IPA, dan ketertarikan siswa terhadap mata pelajaran IPA. Teknik pengumpulan data yang ketiga adalah dokumentasi. Dokumentasi yaitu mendapatkan data hasil jawaban angket minat belajar Ilmu Pengetahuan Alam, data-data siswa kelas III A SD Inpres Lanrai II. Pada penelitian, data angket diperoleh setelah melalui beberapa tahap, yaitu tahap validasi ahli oleh 2 validator. Uji ahli yaitu menguji isi angket berdasarkan kisi-kisi oleh ahli minat. Setelah didapatkan ahli validasi maka angket minat belajar digunakan untuk penelitian di kelas eksperimen.

Nomor item angket terbagi menjadi dua bagian diantaranya item pernyataan yang bernilai positif dan item pernyataan bernilai negatif. Adapun 4 indikator angket minat belajar, yaitu: perasaan suka, keterlibatan siswa, perhatian siswa terhadap mata pelajaran, ketertarikan siswa pada mata pelajaran.

Teknik analisis data yang digunakan ada 2, yaitu: analisis data dengan menggunakan statistik deskriptif dan statistik inferensial. Pengolahan deskriptif untuk menyatakan distribusi frekuensi skor siswa atau menggambarkan minat belajar belajar sebelum dan sesudah pemberian perlakuan serta gambaran penggunaan media video pembelajaran. Pengolahan inferensial digunakan untuk menguji hipotesis yang telah disediakan.

Penelitian ini dilakukan dengan cara memberikan perlakuan dalam pembelajaran dengan menggunakan media video pembelajaran pada kelas eksperimen. Untuk mengetahui ada tidaknya pengaruh penggunaan media video pembelajaran terhadap minat belajar Ilmu Pengetahuan Alam melalui pretest dan posttest yang diberikan sebelum dan sesudah perlakuan, yang kemudian dianalisis menggunakan bantuan program SPSS versi 20.0 .

Pada analisis statistik deskriptif ditemukan minat belajar Ilmu Pengetahuan Alam sebelum diberikan perlakuan adalah sebanyak 1 siswa atau $3,33 \%$ siswa menyatakan bahwa minat belajar IPA berada pada kategori rendah. 25 siswa atau 83,33\% siswa menyatakan bahwa minat belajar IPA berada pada kategori sedang. 4 siswa atau $13,33 \%$ siswa menyatakan minat belajar IPA berada pada kategori tinggi. Selanjutnya setelah diberikan perlakuan maka didapatkan hasil bahwa minat seluruh siswa berada pada kategori tinggi. Dari penjelasan tersebut dapat digambarkan bahwa minat siswa terlihat meningkat setelah diberikan perlakuan video pembelajaran. Selanjutnya adalah analisis inferensial. Hasil analisis inferensial yang terdiri atas uji normalitas pretest dan posttest minat belajar siswa diperoleh nilai sebesar 0,436 dan 0,865 yang artinya lebih besar dari nilai 0,05 sehingga didapatkan bahwa soal pretest dan posttest berdistribusi normal.

Berdasarkan hasil uji hipotesis dengan statistik inferensial menunjukkan ada pengaruh yang signifikan penggunaan media video pembelajaran terhadap minat belajar Ilmu Pengetahuan Alam. Pengambilan keputusan pada pengujian hipotesis menggunakan uji paired sample t-tes dengan program SPSS, diperoleh data nilai signifikansi hasil jawaban pretest dan posttest adalah sig. (2-tailed) 0,000 $<0,05$ berarti Ho diterima dan Ha ditolak. Jadi dapat dikatakan bahwa terdapat pengaruh yang signifikan penggunaan media video pembelajaran IPA terhadap minat belajar siswa kelas III SD Inpres Lanraki II Kecamatan Tamalanrea Kota Makassar.

Video pembelajaran merupakan alat bantu mengajar yang dapat dilihat dan didengar penjelasannya. Kemudian dapat membantu guru menyampaikan tujuan pembelajaran yang ingin dicapai serta memudahkan siswa memahami materi pembelajaran. Penggunaan media video pembelajaran merupakan salah satu alternatif dalam memanfaatkan pengembangan teknologi secara positif. Olehnya itu seorang guru hendaknya mampu membaca situasi perkembangan khususnya merancang pembelajaran dalam kelas sebermakna mungkin.

Video pembelajaran yang digunakan adalah video dari aplikasi Smartedu. Aplikasi tersebut terdapat teks dan tulisan yang berisikan materi pelajaran dan gambar yang berhubungan dengan materi serta video yang menarik yang sesuai dengan materi. Smartedu juga berisikan materi pelajaran kelas III SD, salah satu materinya adalah bentuk bumi. Ketika membuka aplikasi atau software ini akan muncul tampilan yang cukup menarik karena ada suara dari operator software tersebut yang akan memandu untuk memulai menggunakannya, dimulai dari dengan memilih salah satu mata pelajaran yang akan dipelajari, setelah memilih akan muncul tampilan susunan bahan ajar yang akan dipelajari. Selanjutnya operator akan memandu 
untuk mengklik salah satu bahan ajar tersebut, kemudian akan muncul tampilan berdasarkan bahan ajar yang telah diklik sebelumnya. Dalam bahan ajar tersebut operator akan menampilkan materi pembelajaran, dalam materi pembelajaran yang ditampilkan tersebut operator akan membantu menyampaikan atau menjelaskan materi pembelajaran. Dalam Smartedu juga terdapat soal-soal yang dapat dikerjakan dan juga terdapat game interaktif, serta terdapat juga Buku Sekolah Elektronik (BSE) yang berbasis KTSP.

Yunus (Arsyad,2016) merumuskan bahwa media pembelajaran yang memiliki pengaruh besar dan lebih dapat membangkitkan minat mereka adalah media yang tidak hanya dapat dilihat namun juga dapat didengarkan seperti media video pembelajaran sehingga mereka lebih tertarik dan mudah memahami. Sejalan dengan penjelasan tersebut, Hamalik (Arsyad, 2016 : 19) mengemukakan bahwa pemakaian media pembelajaran dalam proses belajar mengajar dapat membangkitkan keinginan dan minat yang baru, membangkitkan motivasi dan rangsangan kegiatan belajar dan bahkan membawa pengaruh-pengaruh psikologi terhadap siswa.

Berdasarkan beberapa penjelasan tersebut, jelas bahwa penggunaan media pembelajaran khususnya video pembelajaran yang menggabungkan suara dan gerak dapat membantu siswa dalam proses pembelajaran. Hal ini dikarenakan video pembelajaran secara otomatis mampu memengaruhi siswa secara emosional melalui tayangan materi atau bahan ajar yang disampaikan yang bersifat kongkrit kepada siswa. Jadi, penggunaan media video dalam pembelajaran akan menciptakan pembelajaran yang diinginkan bukan hanya siswa, tetapi guru bahkan orang tua dalam proses pembelajaran.

\section{KESIMPULAN \& SARAN}

Berdasarkan hasil penelitian dan pembahasan pada bab IV, maka dapat diambil kesimpulan sebagai berikut:

1. Penggunaan media video pada mata pelajaran IPA di kelas III SD Inpres Lanraki II memberikan pengaruh positif terhadap peningkatan minat belajar siswa. Ini dibuktikan dengan hasil pengamatan yang telah dilakukan baik itu kepada siswa maupun kepada guru disetiap pertemuan mengalami peningkatan.

2. Keadaan minat belajar siswa sebelum dilakukan treatment yaitu berada pada kategori sedang. Sedangkan setelah diberikan perlakuan berupa media video pembelajaran maka keadaan minat siswa meningkat yaitu seluruh siswa berada pada kategori tinggi belajar Ilmu Pengetahuan Alam. Hal ini menunjukkan ada peningkatan sebelum dan setelah perlakuan diberikan.

3. Setelah dilakukan uji hipotesis maka didapatkan hasil, terdapat pengaruh yang signifikan penggunaan media video pembelajaran IPA terhadap minat belajar siswa kelas III SD Inpres Lanraki II Kecamatan Tamalanrea Kota Makassar.

Berdasarkan kesimpulan yang dikemukakan, maka diajukan saran sebagai berikut:

1. Bagi Guru

Guru hendaknya senantiasa memberikan treatment kepada siswa khususnya menggunaan media video pembelajaran pada mata pelajaran Ilmu Pengetahuan Alam pada siswa kelas III SD Inpres Lanraki II Kecamatan Tamalanrea Kota Makassar. Hal ini perlu diperhatikan, karena penggunaan media video pembelajaran salah satu hal yang dapat mendukung peningkatan minat belajar Ilmu Pengetahuan Alam.

2. Bagi Siswa

Agar siswa lebih aktif dan berpartisipasi dalam mengikuti pembelajaran di kelas sehingga dapat menciptakan kondisi belajar yang kondusif.

3. Bagi Sekolah

Untuk meningkatkan kemampuan dasar mengajar guru, Sekolah seharusnya lebih memberikan fasilitas dan dukungan dalam mengembangkan keterampilan mengajar khususnya proses belajar IPA, bisa dengan pengadaan LCD Proyektor disetiap kelas atau alat pendukung untuk memutar video pembelajaran.

4. Bagi Peneliti

Peneliti yang akan melakukan penelitian mengenai penggunaan media video terhadap minat siswa mata pelajaran IPA, disarankan agar lebih memperhatikan siswa pada saat observasi sehingga lebih maksimal dalam mengamati siswa.

\section{DAFTAR PUSTAKA}

Adriani, Ria. 2016. Pengaruh Penggunaan Media Video Pembelajaran Terhadap Minat Belajar Siswa Kelas IV SD Inpres Perumnas Kecamatan Rappocini Kota 
Makassar. Skripsi. Makassar: UNM PGSD

Arsyad, Azhar. 2016. Media Pembelajaran. Jakarta: Raja Grafindo Persada.

Bundu, Patta. 2012. Asesmen Pembelajaran. Makassar: Hayfa Press.

Daryanto. 2012. Media Pembelajaran. Bandung: Satu Nusa.

Munir. 2015. Multimedia Konsep dan Aplikasi Dalam Pendidikan. Bandung: Alfabeta.

Musfiqon, HM. 2012. Pengembangan Media dan Sumber Pembelajaran. Jakarta: Prestasi Pustakarya.

Nasution, S. 2004. Didaktik Asas-Asas Mengajar. Jakarta: Bumi Aksara.

Pagarra, Hamzah. 2016. Peningkatan Hasil Belajar Matematika Melalui Model Pembelajaran Problem Solving Pada Siswa Kelas V SDN Kakatua Kecamatan Mariso Kota Makassar: UNM PGSD

Rima, Ega. 2016. Ragam Media Pembelajaran. Kata Pena.

Rusman, dkk. 2013. Pembelajaran Berbasis Teknologi Informasi dan Komunikasi. Jakarta: Rajawali Press.

Sanjaya, Wina. 2012. Media Komunikasi Pembelajaran. Jakarta: Kharisma Putra Utama.

Sardiman, A.M. 2012. Interaksi dan Motivasi Belajar Mengajar. Jakarta: Rajawali.

Sefriana. Andin. 2013. Deteksi Minat bakat Anak. Yogyakarta: Media Pressindo.

Slameto. 2013. Belajar dan Faktor-Faktor yang Mempengaruhinya. Jakarta: Rineka Cipta.

Sugiono. 2016. Metode Penelitian Pendidikan Pendekatan Kuantitatif, Kualitatif, dan $R \& D$. Bandung: Alfabeta.

Sinring, Abdullah, dkk. 2016. Pedomoan Penulisan Skripsi Program S-1. Fakultas Ilmu Pendidikan UNM Makassar.

Suhana, Cucu. 2014. Konsep Strategi Pembelajaran. Bandung: Refika Aditama.

Sukardi. 2011. Metodologi Penelitian Pendidikan.Jakarta : Bumi Aksara.

Susanto, Ahmad. 2013. Teori Belajar dan Pembelajaran Di Sekolah Dasar. Jakarta: KENCANA.

Thomas. 2015. Pengaruh Penggunaan Media Video Pembelajaran Terhadap Keterampilan Proses IPA dan Hasil Belajar IPA Pada Siswa Kelas V SD Negeri Rejowinangun 1 yogyakarta. Skripsi.Yogyakarta: PGSD Universitas Negeri Yogyakarta.
Trianto. 2010. Model Pembelajaran Terpadu. Jakarta: Bumi Aksara.

Undang-undang Republik Indonesia Nomor 20 Tahun 2003 Tentang Sistem Pendidikan Nasional.

Undang-undang Republik Indonesia Tahun 2005 Tentang Guru dan Dosen.

Wahab, Rohmalina. 2015. Psikologi Belajar. Jakarta: Rajawali Pers. 